\title{
Estimating degradation of individual essential amino acids in fish meal and blood meal by rumen microbes in a dual-flow continuous-culture system
}

\author{
S. Gargallo, A. Ferret, and S. Calsamiglia* (i) \\ Animal Nutrition and Welfare Service, Departament de Ciència Animal i dels Aliments, Universitat Autònoma de Barcelona, 08193-Bellaterra, \\ Spain
}

\begin{abstract}
Current feeding systems are based on the assumption that the AA profile of rumen undegraded protein is similar to that of the original feed. The objective of this experiment was to determine rumen bacterial degradation of individual essential AA in fish meal (FM) and blood meal (BM). Eight dual-flow continuous-culture fermentors were used in a completely randomized block design with a factorial arrangement of treatments and 3 replicated periods. Fermentors were supplied with 95 $\mathrm{g}$ of dry matter/d of isonitrogenous diets. Treatments contained a nonprotein $\mathrm{N}$ source (urea and tryptone) that was substituted with increasing proportions of FM or BM $(0,33,67$, or $100 \%)$. Diets consisted of $22.0 \%$ crude protein, $35.2 \%$ neutral detergent fiber, $34.6 \%$ nonfiber carbohydrates, $2.0 \%$ ether extract, and $9.2 \%$ ash. We hypothesized that the increase in the flow of individual AA would be attributed to the increase in the supply of the AA from each protein supplement. True organic matter degradation was decreased by increasing levels of FM or BM, but did not affect degradation of neutral detergent fiber and acid detergent fiber, total volatile fatty acids (VFA) concentration, or the molar proportion of propionate. There was a substrate by level of inclusion interaction in acetate molar proportion and branched-chain VFA. Butyrate concentration decreased linearly with increasing levels of FM and BM in treatment. Changes in branched-chain VFA reflected differences in content of branched-chain AA between supplements and the level of inclusion, although the quadratic effect suggests that other factors were involved. Ammonia-N concentration showed a substrate by level of inclusion interaction. Total dietary $\mathrm{N}$ and AA flows increased with increasing levels of FM or BM in treatment. The efficiency of bacterial crude protein synthesis was not affected by treatment, but the flow of bacterial $\mathrm{N}$ decreased in FM diets as the level of FM in-
\end{abstract}

Received July 17, 2019.

Accepted February 17, 2020.

*Corresponding author: Sergio.Calsamiglia@uab.cat creased. Flows of AA increased linearly with increasing levels of the respective AA from supplements. Arginine, Ile, Met and Phe were more degradable, while His was more resistant to bacterial degradation. Results suggest that the resistance to rumen bacterial degradation of individual AA varies within FM and BM protein and may affect the estimates of dietary supply of individual AA to the small intestine.

Key words: amino acids, bacterial degradation, protein supplements

\section{INTRODUCTION}

Microbial protein supplies 50 to $70 \%$ of total amino AA available in the small intestine of high producing dairy cows; the remaining AA are supplied by dietary undegraded protein (NRC, 2001; Schwab and Broderick, 2017). The AA profile of bacterial protein is close to that of casein, rich in Lys and Met, and relatively constant (Clark et al., 1992; Schwab and Broderick, 2017). In contrast, there are large differences among protein supplements in respect to the amount of AA supplied to the small intestine (Calsamiglia et al., 1995). Most feeds have Lys and Met content in proportions lower than that of casein and bacterial protein (NRC, 2001). Therefore, as the proportion of dietary protein supply to the small intestine increases, the proportional deficit of Lys and Met increases. However, there are some exceptions, such as fish meal (FM) and blood meal (BM). Fish meal is high in Lys $(7.65 \% \mathrm{CP})$ and Met $(2.81 \% \mathrm{CP})$, and BM is high in Lys $(8.98 \% \mathrm{CP})$ when compared with most feeds in dairy cattle diets (NRC, 2001). For this reason, FM and BM are often used as supplements to balance diets for these AA and help alleviate the potential deficits. Feeding systems use the AA profile of feeds to estimate the flow of AA to the small intestine (NRC, 2001; Higgs et al., 2015; INRA, 2018). However, the AA profile of the RUP fraction may differ from that of the original feed, particularly for EAA (Susmel et al., 1989; Maiga et al., 1996; White et al., 2017), which would affect estimates of AA flows to the small intestine. 
While some efforts are being conducted to determine rumen degradability of individual AA in plant protein sources (Maxin et al., 2013; Paz et al., 2014; Gao et al., 2015), less efforts are currently being devoted to explore rumen degradability of AA from animal protein sources (Erasmus et al., 1994; O'Mara et al., 1997). The in situ nylon bag technique provides information on the AA profile of feed residues inside a nylon bag after a single time point incubation (Crooker et al., 1987; Erasmus et al., 1994; Harstad and Prestøkken, 2001). Ruminal degradation of individual AA of feeds can also be determined in vivo with the slope technique, where the intestinal flow of each $\mathrm{AA}$ is regressed against the increasing amounts of the corresponding AA from a protein supplement. However, the methodology is labor intensive, time consuming, and subject to considerable sources of variation (Titgemeyer et al., 1989). The slope technique combined with the use of a dual-flow continuous-culture fermentor allows the implementation of this design to study the effects of bacterial fermentation on AA degradation in protein supplements under controlled conditions. If the fermentation profile and the flow of bacterial protein are similar among treatments, then the linear increase in the supply of FM and BM will result in a linear increase in the flow of individual AA, which can be attributed to the supply of these AA from the respective protein source. The regression of the flow of each individual AA on the supply of AA from each feed will provide the degree of rumen undegradability of each AA within feed.

We hypothesized that the bacterial degradation of individual AA differs within and between FM and BM. The objective of this study was to determine, in a dualflow continuous-culture system, whether the resistance to rumen bacterial degradation of individual AA from FM and BM differs from that of total AA and whether these differences are feed-dependent.

\section{MATERIALS AND METHODS}

\section{Diets and Treatments}

Eight dual-flow continuous-culture fermentors, developed by Hoover et al. (1976) and modified by Devant et al. (2001), were used in a completely randomized block design with a factorial arrangement of treatments. Factors included the protein supplement (Menhaden FM, Omega Protein, Houston, TX; or spray-dried BM, APC Corporation, Granollers, Spain; Table 1) and the isonitrogen substitution of a non-protein mix by the protein supplements tested with the protein mix $(0,33,67$, or 100\%). Fermentors were supplied with $95 \mathrm{~g}$ of DM/d of an isonitrogenous diet that met or exceeded current
Table 1. Chemical (DM basis) and AA composition of fish meal (FM) and blood meal (BM)

\begin{tabular}{lcc}
\hline Composition & FM & BM \\
\hline CP, \% of DM & 76.0 & 94.9 \\
Soluble protein, \% of CP & 22.1 & 16.3 \\
NDF, \% of DM & 6.0 & 0.0 \\
Ether extract, \% of DM & 0.4 & 1.4 \\
Ash, \% of DM & 13.1 & 2.4 \\
NEAA, \% of total AA & 55.37 & 70.1 \\
EAA, \% of total AA & 44.63 & 29.9 \\
Thr & 4.90 & 3.50 \\
Arg & 9.26 & 5.29 \\
Val & 6.66 & 12.7 \\
Met & 4.66 & 1.28 \\
Ile & 5.83 & 1.05 \\
Leu & 8.02 & 16.0 \\
Phe & 4.95 & 15.1 \\
Lys & 9.15 & 8.81 \\
His & 1.95 & 6.42 \\
\hline
\end{tabular}

${ }^{1}$ Includes Ala, Asp, Glu, Gly, Pro, Ser, Tyr.

NRC (2001) nutrient recommendations for lactating dairy cows (Table 2). Diets provided $67 \mathrm{~g}$ of DM/d of a basal diet and $28 \mathrm{~g}$ of DM/d of a mix of NPN composed of urea and tryptone (T9410, Sigma, St. Louis, MO) that was substituted with increasing proportions $(0 \%$, $33 \%, 67 \%$, and $100 \%$ ) of FM or BM. Fish meal was defatted with hexane to prevent potentially negative effects of FM oils on bacterial fermentation (Calsamiglia et al., 1992). Diets were adjusted with wheat straw, corn starch (S4126, Sigma), and limestone to maintain similar nutrient composition across the 8 diets (Table 2 ). All diets were ground at $1.5-\mathrm{mm}$ and fed un-pelleted to prevent the effects of heat on CP degradability.

Dietary treatments were formulated with high CP content $(22 \%)$ with at least $9 \% \mathrm{RDP}$ to ensure sufficient supplies of ammonia, AA, and small peptides for bacterial protein synthesis. The diets contained urea as a source of ruminal ammonia- $\mathrm{N}$ and tryptone as a source of small peptides and AA. The maximal amount of the protein supplement tested (for FM and $\mathrm{BM}$ ) was high to ensure that the change in the flow of individual AA would be large enough to measure in the analysis (Clark et al., 1992; Calsamiglia et al., 1995). We included increasing levels of FM and BM to result in progressive increments of AA supply from the tested proteins. This design was based on previous studies in which these protein supplements were tested in a similar in vitro system (Calsamiglia et al., 1995). The experimental design assumed that the flow of AA from the basal ration and bacteria was similar across treatments. Therefore, when the AA flow was regressed on AA supplied from FM or BM, the changes observed in the AA flow could be attributed exclusively to the protein supplement under study. 


\section{Continuous-Culture System}

We used 8 dual-flow continuous-culture fermentors $(1,320 \mathrm{~mL})$. The trial consisted of 3 replicated periods, where each period had $5 \mathrm{~d}$ for adaptation and $3 \mathrm{~d}$ for sampling. The first day of each period, fermentors were inoculated with rumen fluid obtained from 2 rumenfistulated dairy cows fed a 60:40 forage:concentrate ratio diet (60\% alfalfa hay, $17 \%$ ground corn grain, $8.6 \%$ ground barley grain, $5.0 \%$ soybean meal, $3.4 \%$ molasses, $1.1 \%$ sunflower meal, $1.1 \%$ green peas, $1.1 \%$ lupin seeds, $1.1 \%$ corn gluten feed, and $2.5 \%$ of a vitamin and mineral mix) designed to meet or exceed nutrient recommendations for a Holstein cow producing $30 \mathrm{~kg}$ of milk (NRC, 2001). Rumen fluid was strained through 2 layers of cheesecloth and transported immediately to the laboratory in an insulated thermos. Each fermentor was supplied with a total of $95 \mathrm{~g}$ of $\mathrm{DM} / \mathrm{d}$ of 1 of the 8 experimental diets semicontinuously $(0.66 \mathrm{~g}$ every $10 \mathrm{~min}$ ) to allow for a steady-state fermentation. Fermentor $\mathrm{pH}(6.4 \pm 0.05)$ and temperature $\left(39^{\circ} \mathrm{C}\right)$ were maintained constant by infusion of $3 \mathrm{~N} \mathrm{HCl}$ or 5 $N \mathrm{NaOH}$ (Crison Instruments S.A., Barcelona, Spain) and a thermocouple, respectively. Fermentation conditions were continuously monitored by a programmable linear controller, and fermentation conditions were programmed with Lab View Software (FieldPoint, National Instruments, Austin, TX). Anaerobic conditions of fermentors were achieved through the infusion of $\mathrm{N}_{2}$ at a rate of $40 \mathrm{~mL} / \mathrm{min}$. Artificial saliva was continuously infused into fermentors and contained $0.4 \mathrm{~g} / \mathrm{L}$ of urea to simulate recycled N (Weller and Pilgrim, 1974). Dilution rates were maintained at $10 \% / \mathrm{h}$ for the liquid fraction and $5 \% / \mathrm{h}$ for the solid fraction through the manipulation of rate of saliva input and filtrate suction, using two 8-channel peristaltic pumps (Masterflex Digital Console Drive; Cole-Parmer, Vernon Hills, IL).

\section{Sample Collection}

Filtrate and overflow collection vessels were maintained at $4^{\circ} \mathrm{C}$ during sampling days to stop bacterial fermentation. Each sampling day effluents were weighed, mixed within fermentor, homogenized for 1 min, and sampled. Samples $(500 \mathrm{~mL})$ were removed via aspiration and frozen. At the end of each period, the effluent from the 3 sampling days within fermentor were composited, and subsamples taken for total $\mathrm{N}$, ammonia-N, and VFA analyses. The remainder of the sample was lyophilized and ground through a 1-mm screen. Samples were analyzed for DM, ash, NDF, $\mathrm{ADF}$, purine bases, and AA.

To determine the flow of bacterial $\mathrm{N}$, on the last day of each period solid- and liquid-associated bacteria (SAB and $\mathbf{L A B}$ ) were isolated from fermentor flasks. The LAB fermentor contents were strained through 2

Table 2. Ingredients and chemical composition of experimental diets ${ }^{1}$

\begin{tabular}{|c|c|c|c|c|c|c|c|c|}
\hline Item & FM0 & FM33 & FM67 & FM100 & BM0 & BM33 & BM67 & BM100 \\
\hline Basal mix ${ }^{2}$ & 70.6 & 70.6 & 70.6 & 70.6 & 70.6 & 70.6 & 70.6 & 70.6 \\
\hline Wheat straw & 3.6 & 3.2 & 3.1 & 3.0 & 3.6 & 3.3 & 3.3 & 3.2 \\
\hline Tryptone & 10.7 & 10.1 & 5.1 & - & 10.7 & 7.9 & 3.9 & - \\
\hline Urea & 2.1 & 0.3 & 0.1 & - & 2.1 & 1.0 & 0.5 & - \\
\hline \multicolumn{9}{|c|}{ Chemical composition, \% of DM } \\
\hline $\mathrm{CP}$ & 22.0 & 21.9 & 22.0 & 21.9 & 22.0 & 22.0 & 21.9 & 22.1 \\
\hline $\mathrm{RUP}^{3} \%$ of $\mathrm{CP}$ & 16.9 & 32.1 & 45.1 & 56.7 & 16.9 & 29.6 & 40.8 & 54.6 \\
\hline NDF & 34.3 & 35.2 & 35.1 & 34.0 & 34.3 & 35.0 & 37.8 & 36.2 \\
\hline $\mathrm{ADF}$ & 21.0 & 22.0 & 21.8 & 20.4 & 21.0 & 21.0 & 23.0 & 21.3 \\
\hline $\mathrm{NFC}$ & 38.2 & 32.4 & 32.2 & 32.0 & 38.2 & 36.9 & 30.5 & 36.4 \\
\hline Starch & 27.5 & 21.7 & 21.6 & 21.4 & 27.5 & 26.4 & 19.7 & 26.4 \\
\hline
\end{tabular}

${ }^{1} \mathrm{FM} 0=$ no fish meal $(\mathrm{FM}) ; \mathrm{FM} 33=33 \%$ of supplemental protein from FM; FM67 = 67\% of supplemental protein from FM; FM100 = $100 \%$ of supplemental protein from FM; BM0 = no blood meal (BM); BM33 = 33\% of supplemental protein from BM; BM67 = $67 \%$ of supplemental protein from BM; BM100 = 100\% of supplemental protein from BM.

${ }^{2}$ Contained (g of DM of the diet): alfalfa hay (19.6), corn silage (18.1), barley (16.4), wheat straw (15.1), vitamin-mineral premix (0.54), tryptone (0.54), salt (0.35). One kilogram of DM of vitamin and mineral mixture contained: 1,000,000 IU of vitamin A; 200,000 IU of vitamin D; 1,333 $\mathrm{mg}$ of vitamin $\mathrm{E} ; 300 \mathrm{~g}$ of magnesium oxide; $67 \mathrm{~g}$ of sodium chloride; $33 \mathrm{~g}$ of sulfur; $2.7 \mathrm{mg}$ of manganese sulfate; $7 \mathrm{mg}$ of cobalt sulfate; $167 \mathrm{mg}$ of copper sulfate; $2.7 \mathrm{~g}$ of zinc methionine; $2 \mathrm{~g}$ of zinc sulfate; $33 \mathrm{mg}$ of iodine; $27 \mathrm{mg}$ of selenium; and $267 \mathrm{~g}$ of urea.

${ }^{3}$ RUP estimated with Cornell Net Carbohydrate and Protein System (CNCPS version 6.5: http://blogs.cornell.edu/cncps/software/). 
layers of cheesecloth. The solid fraction was washed with saline solution $(0.85 \% \mathrm{wt} / \mathrm{vol} \mathrm{NaCl})$ to remove residual bacteria of the liquid fraction (Olubobokun and Craig, 1990) and the filtrate was added back to the LAB fraction. The filtrate was centrifuged for $10 \mathrm{~min}$ at $1,000 \times g$ to remove feed particles and the supernatant was centrifuged twice at $20,000 \times g$ for 20 min to isolate LAB. After the first centrifugation, the pellet was washed with saline solution, and after the second centrifugation, the pellet was washed with distilled water to prevent contamination of bacteria with ash. The final bacterial pellet was lyophilized.

The SAB were isolated through an adaptation of the procedures of Whitehouse et al. (1994). In short, fermentor solid residues were suspended in a saline solution containing $0.1 \%$ methylcellulose and incubated for $30 \mathrm{~min}$ in a $37^{\circ} \mathrm{C}$ shaking water bath to remove solid attached bacteria (Minato and Suto, 1978). After the incubation, samples were refrigerated at $4^{\circ} \mathrm{C}$ for $24 \mathrm{~h}$ and then agitated for $1 \mathrm{~h}$ with marbles (thirty 2-mm and fifteen 4-mm diameter marbles) to dislodge loosely attached bacteria. The solid fraction was strained through 2 layers of cheesecloth and washed 3 times with saline solution. The SAB were obtained by differential centrifugation as described for the isolation of LAB. Samples of LAB and SAB were lyophilized and mixed within the fermentor to obtain a unique bacteria sample for each fermentor. Bacteria samples were analyzed for DM, ash, N, and purine bases.

\section{Chemical Analyses}

The DM content of the effluents was determined by lyophilization. Diet and bacteria DM were determined by drying samples for $24 \mathrm{~h}$ in a $103^{\circ} \mathrm{C}$ forced-air oven. Ash content was determined by combustion of samples at $550^{\circ} \mathrm{C}$ overnight in a muffle furnace, and organic matter calculated by difference. Total $\mathrm{N}$ in feed, effluents, and bacteria samples was determined by the Kjeldahl method (AOAC International, 2016; method 976.05). Fiber fractions (NDF and ADF) in feed and effluents were determined sequentially using a thermostable amylase and sodium sulfite (Van Soest et al., 1991; AOAC International, 2016; method 973.18). Ammonia-N concentration was determined by colorimetry (Chaney and Marbach, 1962). Samples for VFA were prepared as described by Jouany (1982) using 4-methylvaleric acid as internal standard and analyzed by gas chromatography (Hewlett Packard, Palo Alto, CA). Effluent and bacterial cells were analyzed for purine bases with a dual-pump HPLC system (Gilson Inc., Middleton, WI) using allopurinol as internal standard (Balcells et al., 1992). Analysis of AA in diet and effluents were conducted according to the procedure of Vendrell and Avilés (1986). In short, diet and effluent samples (5 $\mathrm{mg}$ ) were hydrolyzed in sealed evacuated tubes with $200 \mu \mathrm{L}$ of $6 \mathrm{~N} \mathrm{HCl}$ for $24 \mathrm{~h}$ at $110^{\circ} \mathrm{C}$. Mercaptoethanol was used as a reducing agent to prevent the oxidation of methionine residues during acid hydrolysis. Derivatization was conducted with $200 \mathrm{nmol}$ per tube of dabsyl chloride at $70^{\circ} \mathrm{C}$ for $12 \mathrm{~min}$. Actual amino acid analysis was performed by reversed-phase HPLC (Beckman Instruments, Palo Alto, CA). To reduce determination errors and improve measurement accuracy, lysozyme was used as a standard protein of known AA profile during the digestion process, and norleucine as internal standard for the HPLC analysis. Results were corrected for deviation compared with these standards.

\section{Calculations and Statistical Analyses}

Nutrient digestion and flows were calculated as described by Stern and Hoover (1990). The mixed procedure in SAS (v 9.4, SAS Inst. Inc., Cary, NC) was used to determine the effects of increasing levels of FM and BM on bacterial fermentation profile, nutrient digestion, and individual AA degradation. The model accounted for the random effect of period; the linear, quadratic, and cubic fixed effects of the protein supplement (PS) and the level of inclusion (LI); and their interactions, with the model:

$$
\begin{aligned}
& \mathrm{Y}=\text { Period }(\text { random })+\mathrm{B} 0+\mathrm{B} 0 \times \mathrm{PS}+\mathrm{B} 1 \times \mathrm{LI} \\
& +\mathrm{B} 2 \times \mathrm{LI} \times \mathrm{PS}+\mathrm{B} 3 \times \mathrm{LI}^{2}+\mathrm{B} 4 \times \mathrm{LI}^{2} \times \mathrm{PS} \\
& +\mathrm{B} 5 \times \mathrm{LI}^{3}+\mathrm{B} 6 \times \mathrm{LI}^{3} \times \mathrm{PS}
\end{aligned}
$$

where B0 to B6 are the coefficients for each term. A manual, backward step-wise procedure was used to select the model with the highest order term that was significant at $P \leq 0.05$. The $95 \%$ confidence interval of AA was used to determine whether the degradation of individual AA was different from that of total AA.

\section{RESULTS AND DISCUSSION}

Nutrient composition of BM was within normal ranges, but because FM was defatted, the proportion of all other nutrients increased slightly compared with those reported in NRC (2001). The AA profiles of the 2 supplemental protein sources were also within the ranges reported in NRC (2001; Table 1). True degradation of $\mathrm{OM}$ decreased linearly from an average of $45.5 \%$ in the control to $38.2 \%$ in diets with the highest FM and BM inclusion. This reduction was expected because FM and BM replaced highly degradable sub- 
Table 3. Organic matter truly degraded, fiber degradation, and VFA concentrations and proportions (coefficient and standard error in parentheses) in continuous-culture fermentors that were fed diets containing increasing levels of supplemental $(\mathrm{X}=0,33,67$, and 100\%) fish meal $(\mathrm{FM})$ or blood meal $(\mathrm{BM})$

\begin{tabular}{ll}
\hline Item & Equation $^{1}$ \\
\hline True degradability, $\%$ & \\
OM & $45.5(1.29)-0.07328(0.01733) \mathrm{X}$ \\
NDF & $30.3(1.85)$ \\
ADF & $21.4(1.49)$ \\
Total VFA, mM & $84.0(3.63)$ \\
BCVFA, $^{2} M \mathrm{FM}^{3}$ & $3.44(0.479)+0.009(0.0110) \mathrm{X}-0.00014(0.000107) \mathrm{X}^{2}$ \\
BCVFA, mM BM & $3.76(0.479)-0.031(0.0110) \mathrm{X}-0.00024(0.000107) \mathrm{X}^{2}$ \\
Individual, VFA mol/100 mol & $54.1(1.95)+0.0607(0.05703) \mathrm{X}-0.00095(0.000781) \mathrm{X}^{2}$ \\
Acetate FM & $53.7(1.95)+0.1621(0.05703) \mathrm{X}-0.00224(0.000781) \mathrm{X}^{2}$ \\
Acetate BM & $23.2(1.23)$ \\
Propionate & $14.2(2.09)+0.01287(0.00562) \mathrm{X}$ \\
Butyrate &
\end{tabular}

${ }^{1}$ Only significant terms $(P<0.05)$ are reported.

${ }^{2}$ Branched-chain volatile fatty acids include isobutyrate and isovalerate.

${ }^{3}$ When the protein supplement by level of inclusion interaction was significant, one equation per protein supplement is provided.

strates. However, degradability of $\operatorname{NDF}(30.7 \%)$ and ADF $(20.9 \%)$ were not affected by treatments (Table 3, Supplemental Table S1; https://doi.org/10.3168/ jds.2019-17279). The concentration of total VFA (84.0 $\mathrm{m} M)$ was not affected by treatment. We detected a substrate by level of inclusion interaction in the molar proportion of acetate. No effects of treatments on propionate proportions $(23.2 \mathrm{~mol} / 100 \mathrm{~mol})$ were found. Butyrate concentration decreased linearly as the level of inclusion of protein in both supplements increased (Table 3, Supplemental Table S1). The concentration of branched-chain VFA (BCVFA) followed a quadratic change and was affected by a type of supplement by level of inclusion interaction. These changes reflected the increasing supply of protein supplement and the different content of branched-chain AA between FM and $\mathrm{BM}$, although the quadratic term suggests that other factors affected the concentration of BCVFA.

The effect of dietary treatments on $\mathrm{N}$ metabolism is shown in Table 4 and Supplemental Table S2 (https: //doi.org/10.3168/jds.2019-17279). The ammonia$\mathrm{N}$ concentration and flow followed the same pattern with a substrate by level of inclusion interaction. The change followed a quadratic pattern in FM diets and was reduced linearly in BM diets. In most cases, ammonia- $\mathrm{N}$ was in excess of requirements for rumen bacteria (Wallace et al., 1997), with the exception of the highest inclusion of BM, where ammonia- $\mathrm{N}$ concentration was $30.5 \mathrm{mg} / \mathrm{L}$, well below the minimum level to optimize microbial growth (Satter and Slyter, 1974). However, total flow of bacterial N in BM diets was not affected by the increasing inclusion of BM, even when ammonia- $\mathrm{N}$ fell below the limits. In contrast, bacterial $\mathrm{N}$ flow decreased linearly in the FM diet as the LI of FM increased, and may compromise the underlying assumptions required for the calculations of dietary flows of AA from FM. Clark et al. (1992) reported that increasing dietary RUP tended to reduce bacterial N flow. In a similar in vitro continuous-culture fermentation study, Calsamiglia et al. (1995) did not observe a reduction in bacterial $\mathrm{N}$ flow when $\mathrm{FM}$ and $\mathrm{BM}$ substituted NPN as the main protein source, but the amount of FM and BM supplied in the diet was about half of that in the current experiment. In all cases, the contribution of microbial $\mathrm{N}$ compared with the nonammonia nonmicrobial $\mathrm{N}$ flow was low compared with similar studies (Stern and Hoover, 1979; Calsamiglia et al., 1992, 1995; Brandao et al., 2020). At least part of this low bacterial $\mathrm{N}$ flow can be attributed to the efficiency of bacterial crude protein synthesis. While this efficiency was not affected by treatments (average of $21.0 \mathrm{~g} \mathrm{~N} / \mathrm{kg} \mathrm{OM}$ truly digested), it was in the lower range of values reported in similar experiments (Stern and Hoover, 1979; Brandao et al., 2020). In contrast, nonammonia nonbacterial $\mathrm{N}$ flow linearly increased with the increasing inclusion of low degradable protein sources due to the higher flow of protein from FM and BM, as expected. Dietary CP degradation was not affected by protein source, but decreased as the level of supplemental FM or BM increased in the diet, as expected (Table 4, Supplemental Table S2; https://doi .org/10.3168/jds.2019-17279). It is well established that feeding FM and BM increases the flow of dietary CP to the small intestine (Titgemeyer et al., 1989; Cecava et al., 1990; Clark et al., 1992). The coefficient of the linear equation (Table 4) represents the degradation of protein supplements. Therefore, estimated RUP in FM and $\mathrm{BM}$ in the current experiment was similar at $74 \%$. 
Table 4. Nitrogen metabolism (coefficient and standard error in parentheses) in continuous-culture fermentors that were fed diets containing increasing levels of supplemental protein $(\mathrm{X}=0,33,67$, and $100 \%)$ of fish meal $(\mathrm{FM})$ or blood meal $(\mathrm{BM})$

\begin{tabular}{|c|c|}
\hline Item & Equation $^{1}$ \\
\hline Ammonia-N, mg/dL FM & $52.3(1.43)-0.653(0.06953) \mathrm{X}+0.0041(0.00067) \mathrm{X}^{2}$ \\
\hline Ammonia-N, mg/dL BM & $52.9(1.43)-0.5901(0.06953) \mathrm{X}$ \\
\hline $\begin{array}{l}\text { N Flow, g/d } \\
\text { Ammonia } \text { FM }^{2}\end{array}$ & $1.646(+0.0446)-0.022(+0.0022) X+0.00013(+0.000021) X^{2}$ \\
\hline Ammonia BM & $1.668( \pm 0.0446)-0.0185( \pm 0.00217) \mathrm{X}$ \\
\hline Nonammonia & $2.527( \pm 0.0868)+0.0085( \pm 0.00121) \mathrm{X}$ \\
\hline Bacterial FM & $0.882( \pm 0.0890)-0.0015( \pm 0.00063) \mathrm{X}$ \\
\hline Bacterial BM & $0.816( \pm 0.0890) \mathrm{X}$ \\
\hline $\mathrm{NANM}^{3}$ & $1.679( \pm 0.1168)+0.0091( \pm 0.00116) \mathrm{X}$ \\
\hline $\mathrm{CP}$ degradation, $\%$ & $50.7( \pm 3.44)-0.261( \pm 0.0334) \mathrm{X}$ \\
\hline EMPS $^{4}$ & $21.0( \pm 2.03)$ \\
\hline
\end{tabular}

\footnotetext{
${ }^{1}$ Only significant terms $(P<0.05)$ are presented.

${ }^{2}$ When the protein supplement by level of inclusion interaction was significant, one equation per protein supplement is provided.

${ }^{3} \mathrm{NANM}=$ nonammonia nonmicrobial $\mathrm{N}$ flow $(\mathrm{g} / \mathrm{d})$.

${ }^{4}$ Efficiency of bacterial CP synthesis, in $\mathrm{g}$ of bacterial $\mathrm{N}$ per $\mathrm{kg}$ of OM truly fermented.
}

This value is in the range of RUP reported using the in situ nylon bag technique (59 to $73 \%$ for FM, and 76 to $89 \%$ for BM; Stern et al., 1997).

The total AA flow from fermentors increased as the dietary inclusion level of FM or BM in diets increased, as expected (Table 5), and it was consistent with the reduction in CP degradation observed. Type of protein did not affect the flow of total AA, consistent with the results for CP degradation. Several authors reported increases in total AA flow when feeding low degradable protein sources (Santos et al., 1984; Clark et al., 1992; Calsamiglia et al., 1995). Degradation of EAA was numerically larger than that of NEAA, although not significant. Other authors reported reduced concentrations of EAA in rumen incubated feed residues of FM and $\mathrm{BM}$, reflecting higher rumen microbial degradation of EAA (Crooker et al., 1987; Maiga et al., 1996; O'Mara et al., 1997). In contrast, a summary of data of animal proteins pooled together $(\mathrm{n}=10)$ indicated that EAA were more resistant to ruminal degradation (White et al., 2017). All individual AA equations were linear and suggest that AA degradation was not affected by a potentially excessive amount of protein in the diet. The coefficient of the linear term represents the degradation of the corresponding AA. Among the EAA, Arg, Ile, Met, and Phe were more degradable than the average AA. Other authors reported that the concentration of Ile in BM protein was lower after ruminal exposure compared with the original AA profile (Maiga et al., 1996; Piepenbrink and Schingoethe, 1998). Methionine was more degraded than total AA in both protein supplements. When Titgemeyer et al. (1989) used the slope methodology in vivo, they reported that Met was the most extensively degraded EAA in BM.
Some authors (Blake and Stern, 1988; Susmel et al., 1989; Titgemeyer et al., 1989) also reported that Met was in general more extensively degraded than total AA in several feeds, including FM and BM. In contrast, White et al. (2017) reported that the degradation of Met was feed-dependent and lower than the average AA in animal byproducts. Histidine was the EAA most resistant to degradation in both protein supplements. This may be relevant because His has been suggested to be within the most limiting EAA in dairy cattle (Lee et al., 2012). Our results indicate that some AA in FM and $\mathrm{BM}$ were degraded to a larger extent than the other AA, and this difference should be considered when estimating the flow of individual AA to the small intestine. Messman and Weiss (1994) observed that

Table 5. Equation (coefficient and standard error in parentheses) for the flow of AA $(\mathrm{mg} / \mathrm{d})$ from continuous-culture fermentors that were fed diets containing increasing supply of AA (in $\mathrm{mg} / \mathrm{d}, \mathrm{X}$ ) from fish meal or blood meal

\begin{tabular}{ll}
\hline AA & Equation $^{1}$ \\
\hline Total AA & $12,510(584.1)+0.884(0.1208) \mathrm{X}$ \\
NEAA & $6,961(331.3)+1.090(0.1818) \mathrm{X}$ \\
EAA & $5,544(302.2)+0.803(0.1014) \mathrm{X}$ \\
Arg & $586.4(46.47)+0.697^{*}(0.1194) \mathrm{X}$ \\
His & $213.0(30.50)+1.392^{*}(0.1997) \mathrm{X}$ \\
Ile & $631.0(33.78)^{*}$ \\
Leu & $962.8(70.48)+1.114(0.1402) \mathrm{X}$ \\
Lys & $760.4(48.64)+1.003(0.1124) \mathrm{X}$ \\
Met & $267.2(28.11)+0.629^{*}(0.1456) \mathrm{X}$ \\
Phe & $587.0(40.99)+0.703^{*}(0.1263) \mathrm{X}$ \\
Thr & $705.3(28.30)+0.900(0.1585) \mathrm{X}$ \\
Val & $802.1(50.53)+0.923(0.1228) \mathrm{X}$ \\
\hline
\end{tabular}

${ }^{1}$ Only significant terms are presented $(P<0.05)$. There was no main effect of protein supplements nor interactions.

*Slope differs from that of total AA $(P<0.05)$. 
feeds have a wide range of different proteins, and their AA profile and rumen degradation differ. Therefore, differential degradation of individual AA is likely related to the differences in the structure and AA profile of different proteins within feeds.

Recently, Fleming et al. (2019) developed prediction equations for the flow of AA to the small intestine and reported that the flow of EAA, with the exception of Leu, was consistently overestimated. They attributed this overestimation to methodological problems in the analysis of AA, citing the "under-reporting of true flows in the literature due to recovery problems." However, such under-reporting would also be consistent with a differential higher degradation of EAA when compared with the average AA. In addition to the significant reduction of the coefficient for the flows of Arg, Ile, Met, and Phe, all other EAA (with the exception of His and Leu (Fleming et al., 2019)), were 15\% lower than the average AA and may be a contributing reason to justify the bias. The mean overestimation in the flow of EAA reported by Fleming et al. (2019) is within the range of values of higher degradation of AA reported herein. Furthermore, this difference may be relevant in field conditions. For example, the supply of rumen undegraded Met by $1 \mathrm{~kg}$ of FM $(90 \% \mathrm{DM}, 87 \% \mathrm{CP}$, and $3 \%$ Met) would be $15.5 \mathrm{~g}$ if rumen undegradability of Met is similar to the average CP (66\% RUP; NRC, 2001). It would be $9.3 \mathrm{~g}$ if rumen undegradability of Met is considered to be $60 \%$ lower than the average undegradability of the protein, a reduction of $6.2 \mathrm{~g}$. Similar calculations for $0.5 \mathrm{~kg}$ of BM $(0.90 \%$ DM; $95 \% \mathrm{CP}, 1.5 \%$ Met, $76 \%$ RUP) would result in a reduction of $2.0 \mathrm{~g}$ in the intestinal flow of Met. This reduction in rumen undegraded Met supply from 6.2 to $2.0 \mathrm{~g} / \mathrm{d}$ is within the range of current recommendation for the supplementation of rumen protected methionine products (Patton, 2010). Therefore, the practical implications of the over prediction of Met flow due to the assumption of similar degradability compared with the average degradability of AA is relevant.

Results from the present experiment provide evidence that there are large differences in the degradation of some individual EAA within the feeds tested. However, results should be interpreted with caution. Fiber degradation and total VFA concentrations remained similar across treatments. The changes in VFA proportions among treatments were small. However, the linear reduction in the flow of bacterial $\mathrm{N}$ in FM diets compromises the underlying assumption required to test the hypothesis. Another potential limitation of the experimental design is the potential contribution of AA from tryptone to the flow of AA. Tryptone is hydrolyzed casein and likely degraded at very high rates in the rumen. If we assume a degradation rate of 100 to $200 \% / \mathrm{h}$ (CNCPS, V6.5), the potential contribution of tryptone to the total flow of AA would correspond to a flow of $0.05 \mathrm{~g} \mathrm{~N} / \mathrm{d}$, representing $2.6 \%$ of the total $\mathrm{N}$ flow. Changes in the flow of AA from microbial protein or tryptone may affect estimates of AA flows from FM and BM. However, calculations of differences in bacterial degradation of individual AA in the protein supplements were done relative to the degradation of total AA, therefore these effects would be minimized.

Results from the present experiment and other supporting evidence suggest that some EAA, Met in particular, may be degraded to a larger extent than previously assumed, and may result in an overestimation of the supply of these AA to the small intestine. The conflicting results with the summary by White et al. (2017), where EAA (Met in particular) were more resistant to ruminal degradation, are intriguing. However, their methodology is different than ours. Although data summarized by White et al. (2017) were derived from in situ nylon bag incubation at single points, we report microbial degradation of individual AA under in vitro dynamic fermentation conditions. The slope methodology is a robust design and results are, in spite of the limitations of the methodology, consistent. The limited data available, the large variability among studies, the validation of methodologies, and the effect of potential differences in the degradability between individual AA require further research.

\section{ACKNOWLEDGMENTS}

Financial support was provided by the project AGF97/0444 of the Comisión Interministerial de Ciència y Tecnología of the Spanish Government. The authors have not stated any conflicts of interest.

\section{REFERENCES}

AOAC International. 2016. Official Methods of Analysis. 15th ed. AOAC International, Arlington, VA.

Balcells, J., J. Guada, J. M. Peiró, and D. S. Parker. 1992. Simultaneous determination of allantoin and oxypurines in biological fluids by high performance liquid chromatography. J. Chromatogr. 575:153-157. https://doi.org/10.1016/0378-4347(92)80517-T.

Blake, W. L., and M. D. Stern. 1988. Influence of protein source on amino acid profile of effluent flowing from continuous culture of ruminal contents. J. Anim. Sci. 66:2284-2298. https://doi.org/10 $.2527 / \mathrm{jas} 1988.6692284 \mathrm{x}$.

Brandao, V. L. N., M. I. Marcondes, and A. P. Faciola. 2020. Comparison of microbial fermentation data from dual-flow continuous culture system and omasal sampling technique: A meta-analytical approach. J. Dairy Sci. 103:2347-2362. https://doi.org/10.3168/ jds.2019-17107.

Calsamiglia, S., M. D. Stern, and B. A. Crooker. 1992. Effects of diets formulated to contain different amounts of rumen non-degradable protein on microbial fermentation and nutrient flow from a contin- 
uous culture system. Anim. Feed Sci. Technol. 39:239-252. https:/ /doi.org/10.1016/0377-8401(92)90044-7.

Calsamiglia, S., M. D. Stern, and J. L. Firkins. 1995. Effects of protein source on nitrogen metabolism in continuous culture and intestinal digestion in vitro. J. Anim. Sci. 73:1819-1827. https://doi.org/10 $.2527 / 1995.7361819 x$.

Cecava, M. J., N. R. Merchen, L. L. Berger, and G. C. Fahey Jr.. 1990. Intestinal supply of amino acids in sheep fed alkaline hydrogen peroxide-treated wheat straw-based diets supplemented with soybean meal or combinations of corn gluten meal and blood meal. J. Anim. Sci. 68:467-477. https://doi.org/10.2527/1990.682467x.

Chaney, A. L., and E. P. Marbach. 1962. Modified reagents for determination of urea and ammonia. Clin. Chem. 8:130-132. https:// doi.org/10.1093/clinchem/8.2.130.

Clark, J. H., T. H. Klusmeyer, and M. R. Cameron. 1992. Microbial protein synthesis and flows of nitrogen fractions to the duodenum of dairy cows. J. Dairy Sci. 75:2304-2323. https://doi.org/10 .3168/jds.S0022-0302(92)77992-2.

Crooker, B. A., J. H. Clark, R. D. Shanks, and G. C. Fahey Jr.. 1987. Effects of ruminal exposure on the amino acid profile of feeds. Can. J. Anim. Sci. 67:1143-1148. https://doi.org/10.4141/cjas87-122.

Devant, M., A. Ferret, S. Calsamiglia, R. Casals, and J. Gasa. 2001. Effect of nitrogen source in high-concentrate, low-protein beef cattle diets on microbial fermentation studied in vivo and in vitro. J. Anim. Sci. 79:1944-1953. https://doi.org/10.2527/2001.7971944x.

Erasmus, L. J., P. M. Botha, and C. W. Cruywagen. 1994. Amino acid profile and intestinal digestibility in dairy cows of rumen-undegradable protein from various feedstuffs. J. Dairy Sci. 77:541-551. https://doi.org/10.3168/jds.S0022-0302(94)76982-4.

Fleming, A. J., H. Lapierre, R. R. White, H. Tran, P. J. Kononoff, R. Martineau, W. P. Weiss, and M. D. Hanigan. 2019. Predictions of ruminal outflow of essential amino acids in dairy cattle. J. Dairy Sci. 102:10947-10963. https://doi.org/10.3168/jds.2019-16301.

Gao, W., A. Chen, B. Zhang, P. Kong, C. Liu, and J. Zhao. 2015. Rumen degradability and post-ruminal digestion of dry matter, nitrogen and amino acids of three protein supplements. AsianAustralas. J. Anim. Sci. 28:485-493. https://doi.org/10.5713/ajas .14 .0572

Harstad, O. M., and E. Prestløkken. 2001. Rumen degradability and intestinal indigestibility of individual amino acids in corn gluten meal, canola meal and fish meal determined in situ. Anim. Feed Sci. Technol. 94:127-135. https://doi.org/10.1016/S0377 -8401(01)00304-2.

Higgs, R. J., L. E. Chase, D. A. Ross, and M. E. Van Amburgh. 2015. Updating the Cornell Net Carbohydrate and Protein System feed library and analyzing model sensitivity to feed inputs. J. Dairy Sci. 98:6340-6360. https://doi.org/10.3168/jds.2015-9379.

Hoover, W. H., B. A. Crooker, and C. J. Sniffen. 1976. Effects of differential solid-liquid removal rates on protozoa numbers in continuous cultures of rumen contents. J. Anim. Sci. 43:528-534. https:// doi.org/10.2527/jas1976.432528x.

INRA. 2018. Feeding Systems for Ruminants. Wageningen Academic Publisher, Wageningen, the Netherlands. https://doi.org/10.3920/ 978-90-8686-292-4.

Jouany, J. P. 1982. Volatile fatty acids and alcohol determination in digestive contents, silage juice, bacterial cultures and anaerobic fermentor contents. Sci. Aliments 2:131-144.

Lee, C., A. N. Hristov, T. W. Cassidy, K. S. Heyler, H. Lapierre, G. A. Varga, M. J. de Veth, R. A. Patton, and C. Parys. 2012. Rumenprotected lysine, methionine, and histidine increase milk protein yield in dairy cows fed a metabolizable protein-deficient diet. J. Dairy Sci. 95:6042-6056. https://doi.org/10.3168/jds.2012-5581.

Maiga, H. A., D. J. Schingoethe, and J. E. Henson. 1996. Ruminal degradation, amino acid composition, and intestinal digestibility of the residual components of five protein supplements. J. Dairy Sci. 79:1647-1653. https://doi.org/10.3168/jds.S0022-0302(96)76528 $-1$

Maxin, G., D. R. Ouellet, and H. Lapierre. 2013. Ruminal degradability of dry matter, crude protein, and amino acids in soybean meal, canola meal, corn, and wheat dried distillers grains. J. Dairy Sci. 96:5151-5160. https://doi.org/10.3168/jds.2012-6392.

Messman, M. A., and W. P. Weiss. 1994. Use of electrophoresis to quantify ruminal degradability of protein from concentrate feeds. Anim. Feed Sci. Technol. 49:25-35. https://doi.org/10.1016/0377 -8401(94)90078-7.

Minato, H., and T. Suto. 1978. Technique for fractionation of bacteria in rumen microbial ecosystem. II. Attachment of bacteria isolated from bovine rumen to cellulose powder in vitro and elution of bacteria attached thereform. J. Gen. Appl. Microbiol. 24:1-16. https: //doi.org/10.2323/jgam.24.1.

NRC. 2001. Nutrient Requirements of Dairy Cattle. 7th rev. ed. Nat. Acad. Press, Washington, DC.

O'Mara, F. P., J. J. Murphy, and M. Rath. 1997. The amino acid composition of protein feedstuffs before and after ruminal incubation and after subsequent passage through the intestines of dairy cows. J. Anim. Sci. 75:1941-1949. https://doi.org/10.2527/1997 $.7571941 x$.

Olubobokun, J. A., and W. M. Craig. 1990. Quantity and characteristics of microorganisms associated with ruminal fluid or particles. J. Anim. Sci. 68:3360-3370. https://doi.org/10.2527/1990 68103360x.

Patton, R. A. 2010. Effect of rumen-protected methionine on feed intake, milk production, true milk protein concentration, and true milk protein yield, and the factors that influence these effects: A meta-analysis. J. Dairy Sci. 93:2105-2118. https://doi.org/10 .3168/jds.2009-2693.

Paz, H. A., T. J. Klopfenstein, D. Hostetler, S. C. Fernando, E. Castillo-Lopez, and P. J. Kononoff. 2014. Ruminal degradation and intestinal digestibility of protein and amino acids in high-protein feedstuffs commonly used in dairy diets. J. Dairy Sci. 97:64856498. https://doi.org/10.3168/jds.2014-8108.

Piepenbrink, M. S., and D. J. Schingoethe. 1998. Ruminal degradation, amino acid composition, and estimated intestinal digestibilities of four protein supplements. J. Dairy Sci. 81:454-461. https: /doi.org/10.3168/jds.S0022-0302(98)75597-3.

Santos, K. A., M. D. Stern, and L. D. Satter. 1984. Protein degradation in the rumen and amino acid absorption in the small intestine of lactating dairy cattle fed various protein sources. J. Anim. Sci. 58:244-255. https://doi.org/10.2527/jas1984.581244x.

Satter, L. D., and L. L. Slyter. 1974. Effect of ammonia concentration of rumen microbial protein production in vitro. Br. J. Nutr 32:199-208. https://doi.org/10.1079/BJN19740073.

Schwab, C. G., and G. A. Broderick. 2017. A 100-Year Review: Protein and amino acid nutrition in dairy cows. J. Dairy Sci. 100:1009410112. https://doi.org/10.3168/jds.2017-13320.

Stern, M. D., A. Bach, and S. Calsamiglia. 1997. Alternative techniques for measuring nutrient digestion in ruminants. J. Anim. Sci. 75:2256-2276. https://doi.org/10.2527/1997.7582256x.

Stern, M. D., and W. H. Hoover. 1979. Methods for determining and factors affecting rumen microbial protein synthesis: A review. J. Anim. Sci. 49:1590-1603. https://doi.org/10.2527/jas1979 $.4961590 \mathrm{x}$.

Stern, M. D., and W. H. Hoover. 1990. The dual flow continuous culture system. Pages 17-32 in Proc. Continuous Culture Fermentors: Frustration or fermentation. Northeast ADSA-ASAS Regional Meeting, Chazy, NY. Am. Dairy Sci. Assoc., Champaign, IL.

Susmel, P., B. Stefanon, C. R. Mills, and M. Candido. 1989. Change in amino acid composition of different protein sources after rumen incubation. Anim. Prod. 49:375-383. https://doi.org/10.1017/ S0003356100032591.

Titgemeyer, E. C., N. R. Merchen, and L. L. Berger. 1989. Evaluation of soybean meal, corn gluten meal, blood meal and fish meal as sources of nitrogen and amino acids disappearing from the small intestine of steers. J. Anim. Sci. 67:262-275. https://doi.org/10 $.2527 /$ jas $1989.671262 x$.

Van Soest, P. J., J. B. Robertson, and B. A. Lewis. 1991. Methods for dietary fiber, neutral detergent fiber and nonstarch polysaccharides in relation to animal nutrition. J. Dairy Sci. 74:3583-3597. https://doi.org/10.3168/jds.S0022-0302(91)78551-2. 
Vendrell, J., and F. X. Avilés. 1986. Complete amino acid analysis of proteins by dabsyl derivatization and reversed-phase liquid chromatography. J. Chromatogr. A 358:401-413. https://doi.org/10 .1016/S0021-9673(01)90354-1.

Wallace, R. J., R. Onodera, and M. A. Cotta. 1997. Metabolism of nitrogen-containing compounds. Pages $283-328$ in The Rumen Microbial Ecosystem. 2nd ed. P. N. Hobson and C. S. Stewart, ed. Chapman and Hall, New York, NY. https://doi.org/10.1007/978 -94-009-1453-7_7.

Weller, R. A., and A. F. Pilgrim. 1974. Passage of protozoa and volatile fatty acids from the rumen of a sheep and from a continuous in vitro fermentation system. Br. J. Nutr. 32:341-351. https://doi .org/10.1079/BJN19740087.

White, R. R., P. J. Kononoff, and J. L. Firkins. 2017. Technical note: Methodological and feed factors affecting prediction of ruminal de- gradability and intestinal digestibility of essential amino acids. J. Dairy Sci. 100:1946-1950. https://doi.org/10.3168/jds.2016-12008. Whitehouse, N. L., V. M. Olson, C. G. Schwab, W. R. Chesbro, K. D. Cunningham, and T. Lykos. 1994. Improved techniques for dissociating particle-associated mixed ruminal microorganisms from ruminal digesta solids. J. Anim. Sci. 72:1335-1343. https://doi.org/ $10.2527 / 1994.7251335 x$.

\section{ORCIDS}

S. Calsamiglia @ https://orcid.org/0000-0002-0978-3799 